\title{
Stable isotopes reveal the trophic position and mesopelagic fish diet of female southern elephant seals breeding on the Kerguelen Islands
}

\author{
Y. Cherel ${ }^{1, *}$, S. Ducatez ${ }^{1}$, C. Fontaine ${ }^{1}$, P. Richard ${ }^{2}$, C. Guinet ${ }^{1}$ \\ ${ }^{1}$ Centre d'Etudes Biologiques de Chizé, UPR 1934 du CNRS, BP 14, 79360 Villiers-en-Bois, France \\ ${ }^{2}$ Centre de Recherche sur les Ecosystèmes Littoraux Anthropisés, UMR 6217 du CNRS-IFREMER-ULR, Place du Séminaire, \\ BP 5, 17137 L'Houmeau, France
}

\begin{abstract}
Trophic interactions between organisms are the main drivers of ecosystem dynamics, but scant dietary information is available for wide-ranging predators during migration. We investigated feeding habits of a key consumer of the Southern Ocean, the southern elephant seal Miroungia leonina, by comparing its blood $\delta^{13} \mathrm{C}$ and $\delta^{15} \mathrm{~N}$ values with those of various marine organisms, including crustaceans, squid, fishes, seabirds and fur seals. At the end of winter, $\delta^{13} \mathrm{C}$ values $(-23.1$ to $-20.1 \%$ ) indicate that female elephant seals forage mainly in the vicinity of the Polar Front and in the Polar Frontal Zone. Trophic levels derived from $\delta^{15} \mathrm{~N}$ values (trophic level $=4.6$ ) show that the southern elephant seal is a top consumer in the pelagic ecosystem that is dominated by colossal squid. The mean $\delta^{15} \mathrm{~N}$ value of seals $(10.1 \pm 0.3 \%$ o indicates that they are not crustacean eaters, but instead feed on crustacean-eating prey. Surprisingly, most of the previously identified prey species have isotope $\delta^{13} \mathrm{C}$ and $\delta^{15} \mathrm{~N}$ values that do not fit with those of potential food items. The most singular pattern to emerge from $\delta^{15} \mathrm{~N}$ values of predators and prey is that female seals are likely to feed on myctophid fishes, not squid or Patagonian toothfish. We therefore suggest that they occupy a unique trophic niche amongst the guild of air-breathing, diving vertebrates by feeding on mesopelagic fish at great depths. In turn, this finding emphasizes the role of myctophids in oceanic waters and will help to quantify and model fluxes of matter and energy within the pelagic ecosystem of the Southern Ocean.
\end{abstract}

KEY WORDS: Cephalopod · Mesopelagic fish · Myctophid $\cdot$ Pelagic ecosystem · Southern Ocean · Squid

Resale or republication not permitted without written consent of the publisher

\section{INTRODUCTION}

The southern elephant seal Mirounga leonina is the largest phocid species and its abundance and body mass make it a major consumer of marine resources in the Southern Ocean (Guinet et al. 1996, Hindell et al. 2003). The use of sophisticated electronic devices over the last decade has shown that, depending on age and sex, southern elephant seals forage in deep waters (300 to $600 \mathrm{~m}$ ) over wide marine areas during their postmolt and postbreeding trips (Hindell et al. 1991, 2003, Biuw et al. 2007). The identities of their prey are still largely unknown because $M$. leonina forage far away from land and have almost empty stomachs when they return. Indeed, stomach lavage has collected only hard parts of prey species, mainly cephalopod beaks, thus suggesting a strong bias and overestimation towards items that resist digestion and accumulate over time (Rodhouse et al. 1992, Green \& Burton 1993, Slip 1995). Moreover, dietary samples are only representative of the very last portion of the trip, not of prey consumed over the entire foraging area. These biases lead to the common, but poorly supported, thought that southern elephant seals are mainly teuthivorous (Whitehead et 
al. 2003), and thus to the estimation that their total annual consumption was about 4.5 million tonnes of prey, primarily oceanic squid (Santos et al. 2001).

Since disentangling the trophodynamics within food webs is an important first step for a better overall understanding of ecosystem functioning, recently developed methods of diet analysis, e.g. fatty acids and stable isotopes, are now increasingly used to investigate the feeding habits of major consumers. These methods are based on the common principle that 'you are what you eat', i.e. the biochemical composition of molecules and tissues of consumers reflects that of their food in a predictable manner (Kelly 2000). For example, consumer tissues are enriched in ${ }^{15} \mathrm{~N}$ relative to their food and, consequently, $\delta^{15} \mathrm{~N}\left({ }^{15} \mathrm{~N} /{ }^{14} \mathrm{~N}\right)$ measurements serve as indicators of a consumer trophic position. In contrast, $\delta^{13} \mathrm{C}\left({ }^{13} \mathrm{C} /{ }^{12} \mathrm{C}\right)$ values vary little along the food chain and are mainly used to determine primary sources in a trophic network. In the marine environment, $\delta^{13} \mathrm{C}$ values indicate consumer foraging areas (i.e. inshore versus offshore, pelagic versus benthic) or latitudinal variation in the contribution to food intake (Kelly 2000, Cherel \& Hobson 2007).

In contrast to previous dietary analyses based on examination of stomach contents, the use of fatty acids as trophic markers was consistent with elephant seals having a fish-based diet (Brown et al. 1999) or a fish and squid diet, depending on the location of the foraging grounds (Bradshaw et al. 2003), hence the call for further analyses to determine the relative importance of squid versus fish in its food (Brown et al. 1999). To our knowledge, the stable isotope method was only used once for southern elephant seals, but, due to the lack of appropriate reference collections, prey species were not identified (Lewis et al. 2006). In the present study, we determine whether blood $\delta^{13} \mathrm{C}$ and $\delta^{15} \mathrm{~N}$ values can indicate the feeding habits of adult female southern elephant seal (hereafter elephant seal) breeding on the Kerguelen Islands, southern Indian Ocean. We built up 3 unique datasets to interpret the $\delta^{13} \mathrm{C}$ and $\delta^{15} \mathrm{~N}$ values of seals relative to those of various marine organisms from the Southern Ocean.

The first dataset comprised isotopic data from Kerguelen penguins and fur seals, i.e. the guild of airbreathing diving vertebrates to which elephant seals belong. Penguins and fur seals breeding in the southern Indian Ocean occupy a wide range of trophic niches, including pelagic/oceanic and benthic/neritic species and both fish and crustacean eaters (Lescroel \& Bost 2005, Lea et al. 2006, Cherel et al. 2007). The second set of data included $\delta^{13} \mathrm{C}$ and $\delta^{15} \mathrm{~N}$ values from soft tissues of the main known pelagic resources from the Southern Ocean targeted by marine mammals and seabirds. Since female elephant seals dive pelagically from Kerguelen to the Polar Front and Antarctic waters
(Biuw et al. 2007), we focused on subantarctic and Antarctic swarming crustaceans (2 euphausids and 1 hyperiid amphipod), 2 main subantarctic and Antarctic squid, and the 4 most abundant myctophid fishes that form the bulk of mesopelagic fish biomass in the Southern Ocean (Kozlov 1995). Remains from all these species were previously found in variable amounts in stomach contents of elephant seals (Slip 1995, Field et al. 2007). We also determined the $\delta^{13} \mathrm{C}$ and $\delta^{15} \mathrm{~N}$ values of Patagonian toothfish living in slope waters, because the species was suggested to be a main prey of elephant seals (Brown et al. 1999). The third dataset was built using recently published $\delta^{13} \mathrm{C}$ and $\delta^{15} \mathrm{~N}$ values of cephalopods living in Kerguelen waters, based on measurements of squid beaks (Cherel \& Hobson 2005). The Kerguelen community is composed of almost all the main oceanic squid occurring in the Southern Ocean, including the giant and colossal squid. Finally, we estimated the trophic level (TL) of elephant seals using their $\delta^{15} \mathrm{~N}$ values and compared it with those of other consumers to verify the common assumption that marine mammals are top predators in marine ecosystems (Bradshaw et al. 2003, Field et al. 2007).

\section{MATERIALS AND METHODS}

Fieldwork was carried out at Kerguelen Islands $\left(49^{\circ} 21^{\prime} \mathrm{S}, 70^{\circ} 18^{\prime} \mathrm{E}\right)$, located in the southern part of the Polar Frontal Zone in the immediate vicinity of the Polar Front (Park \& Gambéroni 1997). A blood sample was taken from randomly chosen female southern elephant seals during the breeding period (early spring 2006), and from lactating female Antarctic fur seals Arctocephalus gazella and adults of each species of penguin in spring 2002 (first dataset). Macaroni and rockhopper penguins (Eudyptes chrysolophus and E. chrysocome filholi, respectively) were captured just after their arrival in the colony to breed, while king and gentoo penguins (Aptenodytes patagonicus and Pygoscelis papua, respectively) were parent birds feeding chicks. The second dataset included pelagic crustaceans and fish that were collected at night in January 2005 in oceanic waters east of the Kerguelen Archipelago using an International Young Gadoid Pelagic Trawl. Patagonian toothfish Dissostichus eleginoides were caught on bottom longlines in Kerguelen slope waters in May 2006, and warty squid Moroteuthis ingens during trawl operations in September 2006.

To further constrain the foraging ecology of highly migratory elephant seals, values of species spanning a latitudinal gradient in carbon stable isotopes (Cherel \& Hobson 2007) were used. First, a subtropical species, lactating female subantarctic fur seals Arctocephalus tropicalis from Amsterdam Island (375 $\left.51^{\prime} \mathrm{S}, 77^{\circ} 31^{\prime} \mathrm{E}\right)$, 
and second, a high-Antarctic species, Adélie penguins Pygoscelis adeliae from Adélie Land $\left(66^{\circ} 40^{\prime} \mathrm{S}\right.$, $140^{\circ} 01^{\prime} \mathrm{E}$ ) at the beginning of their breeding cycle. Finally, barely digested Antarctic krill Euphausia superba and the squid Psychroteuthis glacialis were sorted from emperor penguin vomits found on the sea-ice in Adélie Land (Cherel 2008).

Once specimens of invertebrates and fish were identified, whole crustaceans and pieces of squid and fish muscle (see Table 1) were collected for isotopic analysis and kept at $-20^{\circ} \mathrm{C}$. Whole blood of pinnipeds and penguins was kept in $70 \%$ ethanol. After being dried in an oven at $60^{\circ} \mathrm{C}$, crustaceans and muscle samples were ground to a fine powder and lipids were extracted using cyclohexane. The low blood lipid content does not typically necessitate lipid extraction (Cherel et al. 2005a,b). Carbonates were removed prior to lipids from crustaceans using $1 \mathrm{~mol} \mathrm{HCl} \mathrm{l}^{-1}$. Relative abundance of ${ }^{13} \mathrm{C}$ and ${ }^{15} \mathrm{~N}$ were determined using an Isoprime (Micromass) continuous-flow isotope-ratio mass spectrometer. Results are presented in the usual $\delta$ notation relative to Pee Dee Belemnite and atmospheric $\mathrm{N}_{2}$ (air) for $\delta^{13} \mathrm{C}$ and $\delta^{15} \mathrm{~N}$, respectively.

To compare TL of pelagic organisms based on isotopic measurement, the following equation was used for invertebrates and fish:

$$
\mathrm{TL}_{\mathrm{x}}=\left[\left(\delta^{15} \mathrm{~N}_{\mathrm{x}}-3.4\right) / 3.2\right]+2.0
$$

where $\delta^{15} \mathrm{~N}_{\mathrm{x}}$ is the nitrogen isotope ratio of animal ' $\mathrm{x}$ ', $3.4 \%$ is the average value for Salpa thompsoni, a dominant herbivorous salp (Perissinotto \& Pakhomov 1998) in Kerguelen oceanic waters with an assumed TL of 2.0, and $3.2 \%$ is the average trophic enrichment factor between the muscle of fish and their food (Sweeting et al. 2007). The latter value is close to that of the cuttlefish Sepia officinalis, the only cephalopod species so far investigated (3.3\%, Hobson \& Cherel 2006). Since enrichment factors vary with prey and predator tissue types, we used $1.7 \%$ as the enrichment factor between prey muscle and pinniped and penguin blood (Hobson et al. 1996, Lesage et al. 2002, Cherel et al. 2005b), and the following equation for estimated TL of mammals and birds:

$$
\mathrm{TL}_{\mathrm{x}}=\left[\left(\delta^{15} \mathrm{~N}_{\mathrm{x}}-3.4-1.7\right) / 3.2\right]+3.0
$$

The isotopic values of elephant seals were not corrected when compared to the $\delta^{15} \mathrm{~N}$ and the $\delta^{13} \mathrm{C}$ values of marine organisms (second and third datasets) because (1) the enrichment factors are small relative to the spread of the data, and (2) statistical results were used not only to define the seal diet but also to look at the overall structure of the food web. Cephalopod beaks were depleted in ${ }^{15} \mathrm{~N}$ and enriched in ${ }^{13} \mathrm{C}$ when compared to muscle tissue. The $\delta^{13} \mathrm{C}$ and $\delta^{15} \mathrm{~N}$ values of beaks were consequently corrected in the third dataset by adding $4.9 \%$ to and subtracting $0.8 \%$ from their $\delta^{15} \mathrm{~N}$ and $\delta^{13} \mathrm{C}$ values, respectively, which correspond to the mean isotopic differences between lower beak and muscle of cephalopods (Cherel \& Hobson 2005, Hobson \& Cherel 2006). Data were statistically analysed using SYSTAT 9. Values are mean \pm SD.

\section{RESULTS}

At Kerguelen, the 6 species of sympatric pinnipeds and penguins (first dataset) were segregated by their overall carbon and nitrogen stable isotope values (MANOVA, Wilk's lambda, $F_{10,176}=67.04, \mathrm{p}<0.0001$ ) and, in univariate analysis, in their $\delta^{13} \mathrm{C}$ (ANOVA, $\left.F_{5,89}=45.05, \mathrm{p}<0.0001\right)$ and $\delta^{15} \mathrm{~N}$ values for blood $\left(F_{5,89}=107.53, \mathrm{p}<0.0001\right)$ (Table 1$)$. Post hoc Tukey's HSD multiple comparison tests indicated that (1) gentoo penguins had a significantly higher $\delta^{13} \mathrm{C}$ value than the other 5 species (all p $<0.0001$ ), and (2) female southern elephant seals had an isotopic value not statistically different from those of female Antarctic fur seals, king penguins and the 2 species of crested penguins (Fig. 1). Comparison tests showed that $\delta^{15} \mathrm{~N}$ values of macaroni and rockhopper penguins were significantly lower than those of the other species (all p < $0.0001)$, and, interestingly, that the $\delta^{15} \mathrm{~N}$ value of elephant seals was slightly, but significantly, different from that of Antarctic fur seals ( $p=0.023)$, but not from that of king penguins. Elephant seals also segregated from species known to forage in either high-Antarctic (Adélie penguins) or subtropical (subantarctic fur seals) waters by both their $\delta^{13} \mathrm{C}$ and $\delta^{15} \mathrm{~N}$ values (2-sample $t$-tests, $t=15.44$ and 19.45, and 12.71 and 25.38, respectively, all $\mathrm{p}<0.0001$ ).

Elephant seals and subantarctic and Antarctic crustaceans, fish and squid (second dataset) were segregated by both $\delta^{13} \mathrm{C}$ (ANOVA, $F_{10,136}=128.85, \mathrm{p}<$ $0.0001)$ and $\delta^{15} \mathrm{~N}$ values $\left(F_{10,136}=237.48, \mathrm{p}<0.0001\right)$. Multiple comparison tests indicated that Patagonian toothfish, Psychroteuthis glacialis and Antarctic krill had higher and lower $\delta^{13} \mathrm{C}$ values than the other species, respectively (all $\mathrm{p}<0.004$ ). Otherwise, the $\delta^{13} \mathrm{C}$ value of elephant seals was not statistically different from those of the myctophids Electrona antarctica, E. carlsbergi and Gymnoscopelus nicholsi, but it was significantly different from that of Krefftichthys anderssoni $(\mathrm{p}=0.001)$. Its higher $\delta^{15} \mathrm{~N}$ value segregated toothfish from other marine organisms (all $p<0.0001$ ), while the 3 crustacean species segregated from fishes, squid and seal by their lower $\delta^{15} \mathrm{~N}$ values (all p < $0.0001)$. The $\delta^{15} \mathrm{~N}$ value of elephant seals was higher than those of E. antarctica ( $p<0.0001)$, E. carlsbergi $(p=0.017)$ and $K$. anderssoni $(p<0.0001)$, but not statistically different from the values of $G$. nicholsi and warty squid (Fig. 2). 


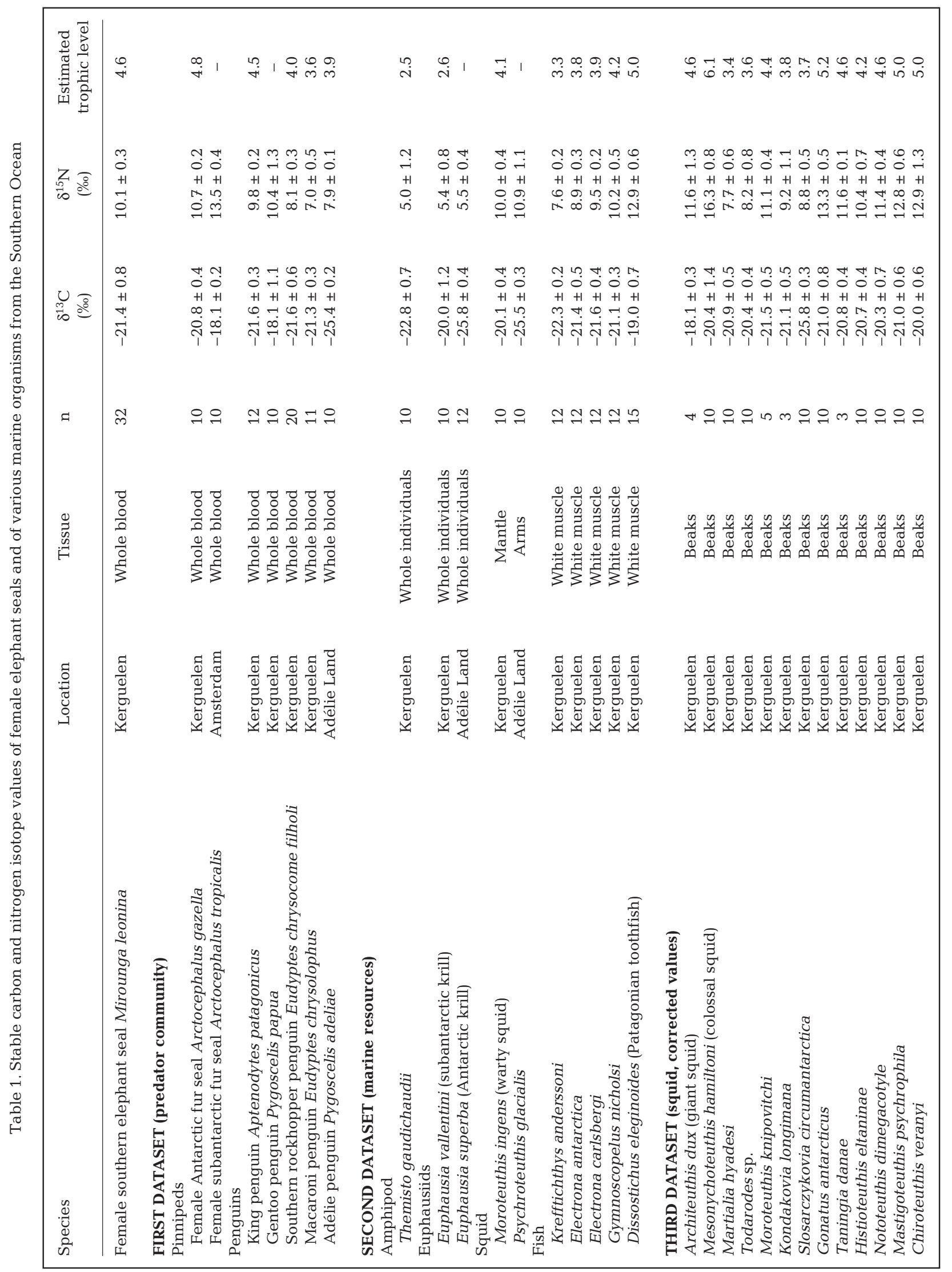




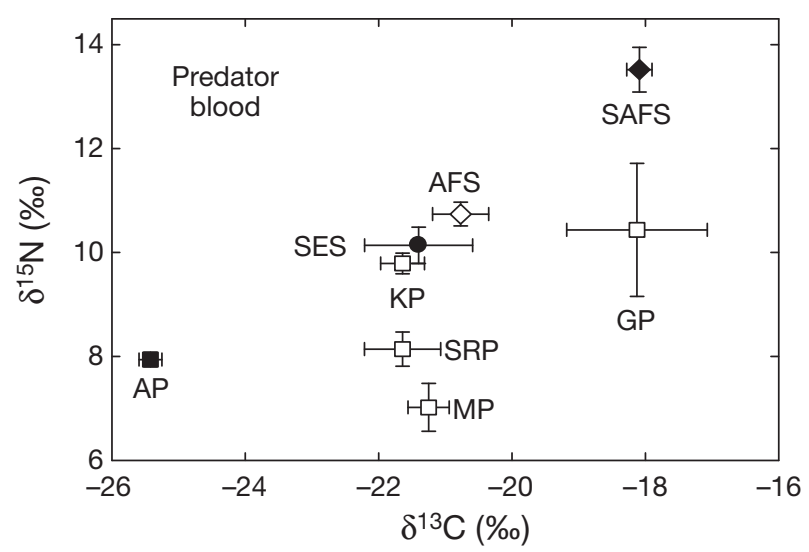

Fig. 1. Stable carbon and nitrogen isotope values in whole blood of elephant seals and other air-breathing diving predators. AFS: female Antarctic fur seal (Kerguelen); AP: Adélie penguin (Adélie Land, Antarctica); GP: gentoo penguin (Kerguelen); KP: king penguin (Kerguelen); MP: macaroni penguin (Kerguelen); SAFS: subantarctic fur seal (Amsterdam, subtropics); SES: female southern elephant seal (Kerguelen); SRP: southern rockhopper penguin (Kerguelen)

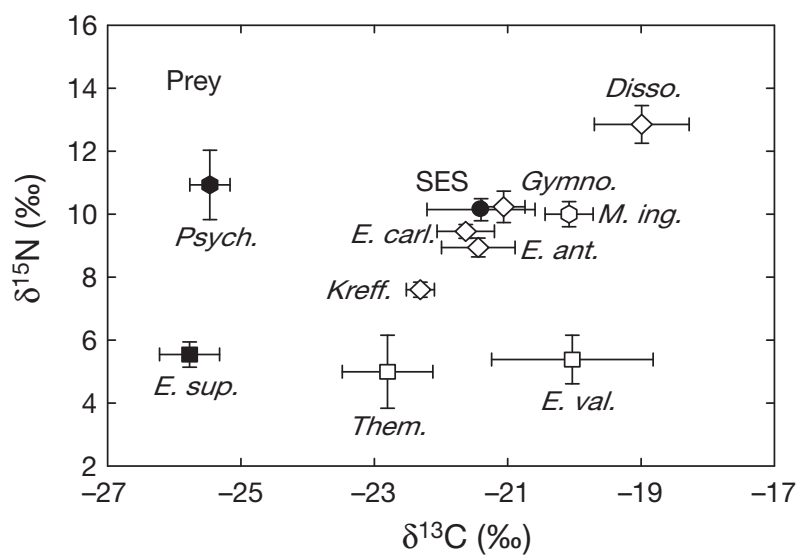

Fig. 2. Stable carbon and nitrogen isotope values in whole blood of elephant seals and in muscle (fish) and whole specimens (crustaceans) of potential prey from Kerguelen Islands (open symbols) and Antarctica (filled symbols). Disso.: Dissostichus eleginoides (Patagonian toothfish); E. ant.: Electrona antarctica (myctophid); E. carl.: Electrona carlsbergi (myctophid); E. sup.: Euphausia superba (Antarctic krill); E. val.: Euphausia vallentini (subantarctic krill); Gymno.: Gymnoscopelus nicholsi (myctophid); Kreff.: Krefftichthys anderssoni (myctophid); $M$. ing.: Moroteuthis ingens (warty squid); Psych.: Psychroteuthis glacialis (squid); SES: female southern elephant seal; Them.: Themisto gaudichaudii (amphipod)

Elephant seals and Kerguelen squid (third dataset) were segregated by their $\delta^{13} \mathrm{C}$ and $\delta^{15} \mathrm{~N}$ values (Kruskal-Wallis, $H=71$ and 123, respectively, both $\mathrm{p}<$ 0.0001). Except Slosarczykovia circumantarctica and the giant squid Architeuthis dux (all p < 0.0001), squid species showed a restricted range in $\delta^{13} \mathrm{C}$ values, with elephant seals having a $\delta^{13} \mathrm{C}$ value that was not statistically different from those of Gonatus antarcticus, His- tioteuthis eltaninae, Kondakovia longimana, Martialia hyadesi, Mastigoteuthis psychrophila, Moroteuthis knipovitchi and Taningia danae. The colossal squid Mesonychoteuthis hamiltoni had the highest $\delta^{15} \mathrm{~N}$ value (all $\mathrm{p}<0.0001$ ), which was much higher than that of elephant seals (Fig. 3). Only 3 squid species (S. circumantarctica and juvenile Martialia hyadesi and Todarodes sp.) had $\delta^{15} \mathrm{~N}$ values significantly lower than elephant seals (all p $<0.0001$ ), with 3 other species (Histioteuthis eltaninae, K. longimana and Moroteuthis knipovitchi) having similar values to seals.

Estimated TLs within the community of Kerguelen consumers ranged from 2.5 (the amphipod Themisto gaudichaudii) to 6.1 (colossal squid), with southern elephant seals having an intermediate position (TL = 4.6). Four squid species and the Patagonian toothfish had a much higher TL $(\geq 5.0)$ than elephant seals, which shared the same TL (4.5 to 4.6$)$ as 3 squid species and the king penguin (Table 1 ).

\section{DISCUSSION}

This study is the first, to our knowledge, to investigate the TL and dietary habits of elephant seals by comparing their blood isotopic values with the values for a large range of marine organisms from the Southern Ocean. The stable isotope method is based on time-integrated assimilated food, thus contrasting with the snapshot of stomach content analysis. Blood of

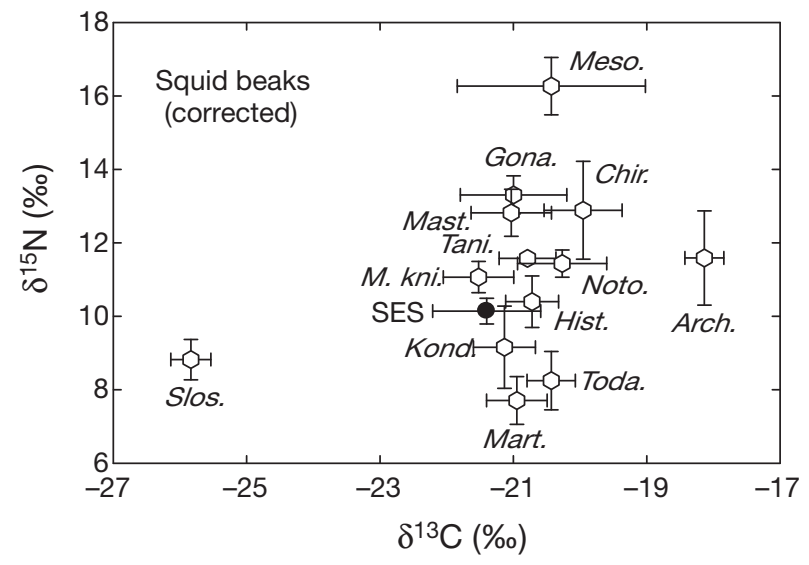

Fig. 3. Stable carbon and nitrogen isotope values in whole blood of elephant seals (SES, filled symbol) and in chitinized beaks of potential squid prey from Kerguelen Islands. Isotope values of beaks were corrected (see 'Materials and methods'). Arch.: Architeuthis dux (giant squid); Chir.: Chiroteuthis veranyi; Gona.: Gonatus antarcticus; Hist.: Histioteuthis eltaninae; Kond.: Kondakovia longimana; Mart.: Martialia hyadesi; Mast.: Mastigoteuthis psychrophila; Meso.: Mesonychoteuthis hamiltoni (colossal squid); M. kni.: Moroteuthis knipovitchi; Noto.: Nototeuthis dimegacotyle; SES: female southern elephant seal; Slos.: Slosarczykovia circumantarctica; Tani.: Taningia danae; Toda.: Todarodes sp. 
large mammals integrates a period of 2 to 3 mo (Hilderbrand et al. 1996), corresponding here to the food consumed by female elephant seals at the end of the austral winter, during the last part of their 8 mo postmolt foraging trip. The stable isotope values of consumers may be affected by various extrinsic and intrinsic processes, including ecological gradients at the base of the food webs and physiological status of the animals. Seals fast during lactation but, in agreement with little changes in $\delta^{13} \mathrm{C}$ and $\delta^{15} \mathrm{~N}$ values of penguin blood with fasting (Cherel et al. 2005a), preliminary investigations on female elephant seals have shown no significant differences in blood carbon and nitrogen values between the beginning and the end of the lactation period (Ducatez et al. 2008). Variation in $\delta^{15} \mathrm{~N}$ values in consumers may result not only from the TL at which they feed, but also from changes at the base of the food web. $\delta^{15} \mathrm{~N}$ values of oceanic particulate organic matter (POM) vary spatiotemporally in the Southern Ocean (Altabet \& François 1994, Lourey et al. 2003), and these changes can potentially affect our calculation of TL. For example, the large $\delta^{15} \mathrm{~N}$ gradients at the Subtropical Front (Altabet \& François 1994) and between neritic and oceanic waters at Kerguelen (Cherel \& Hobson 2007) precluded the accurate estimation of TL for the neritic gentoo penguin and subantarctic fur seals foraging in subtropical waters (Table 1). However, latitudinal variation in POM $\delta^{15} \mathrm{~N}$ is relatively low in oceanic waters of the Southern Ocean, and seasonal variation is integrated and buffered all along the food web, from short-lived phytoplankton to long-lived predators. Finally, little effect of temporal variation in POM isotope baseline levels was also indicated by the consistency of $\delta^{13} \mathrm{C}$ and $\delta^{15} \mathrm{~N}$ values of female seals over time, since seals sampled in other years (2004-2007) and seasons (pre- and postmolt trips) had $\delta^{13} \mathrm{C}$ and $\delta^{15} \mathrm{~N}$ values not significantly different from those sampled in 2006 (authors' unpubl. data).

Inshore/offshore and latitudinal gradients in $\delta^{13} \mathrm{C}$ values helped us to delineate foraging areas of female elephant seals from Kerguelen. Elephant seal carbon values were much more positive than those of Antarctic organisms and more negative than those of fur seals breeding in the subtropics, showing that they foraged neither in cold waters surrounding the Antarctic continent nor in warmer subtropical waters north of the Subtropical Front. Instead, their $\delta^{13} \mathrm{C}$ values (from -23.1 to $-20.1 \%$ ) indicated that, depending on individuals, female elephant seals fed from medium and/or low latitudes of the Antarctic Zone to the Subantarctic Zone, including the Polar Frontal Zone. The $\delta^{13} \mathrm{C}$ values of elephant seals were also much more negative than those of the neritic forager, the gentoo penguin, showing that they did not forage over the Kerguelen shelf $(<200 \mathrm{~m})$. The seal $\delta^{13} \mathrm{C}$ value was thus in general agreement with tracking data showing that adult females travel quickly over the shelf to forage over wide oceanic areas of the Southern Ocean in winter (Hindell et al. 2003, Lewis et al. 2006).

Pinnipeds, including elephant seals, are generally considered to be top predators, sharing a place at the highest TLs of the food web with seabirds and some large pelagic fish. However, evidence from stable isotopes indicates that this common paradigm is questionable. When compared to other consumers from the Southern Ocean, including those considered as from lower TLs (e.g. some mesopelagic fish and squid), there was significant overlap. Moreover, the most singular pattern to emerge from estimated TLs was that the colossal squid ( $\mathrm{TL}=6.1$ ), and, to a lesser extent, the Patagonian toothfish (5.0), were the highest top consumers in Kerguelen waters, but not giant squid (4.6), pinnipeds (4.6 to 4.8 ) or penguins (3.6 to 4.5 ). Derived TLs from $\delta^{15} \mathrm{~N}$ values showed that marine mammals (including elephant seals) and seabirds belong to the upper levels of the trophic web, but most of these species do not occupy the highest levels, as does the polar bear in the high-Arctic (Hobson et al. 2002).

Nitrogen values of penguins and fur seals at Kerguelen (first dataset) agreed with the known trophic structure of the community and feeding ecology of the species, i.e. the fish-eating king penguins and female Antarctic fur seals were one TL higher than the crustacean-eating macaroni and rockhopper penguins and the Antarctic Adélie penguin (Ridoux \& Offredo 1989, Lea et al. 2006, Cherel et al. 2007). Within that community, the $\delta^{15} \mathrm{~N}$ value of elephant seals was higher (about $1 \mathrm{TL}$ ) than those of both species of crested penguins, and was much higher (about 2 TL) than those of euphausiids and amphipods. Taken together, these data indicated that elephant seals fed on crustaceaneating prey and were thus not primarily crustacean eaters, which is in agreement with both stomach content and blubber and milk lipid analyses (Slip 1995, Brown et al. 1999, Bradshaw et al. 2003).

The 3 isotopic datasets shed new light on the old debate about the relative proportions of squid versus fish in the diet of elephant seals. The mean nitrogen isotope value of female seals was not statistically different from that of king penguins and was close to that of Antarctic fur seals, 2 consumers that feed primarily on lanternfish (Myctophidae) (Cherel at al. 2002, Lea et al. 2006). Myctophids (Electrona antarctica, E. carlsbergi and Krefftichthys anderssoni) are crustacean eaters (Gaskett et al. 2001), and their $\delta^{15} \mathrm{~N}$ and $\delta^{13} \mathrm{C}$ values fit well with those of theoretical prey of elephant seals (second dataset). Myctophids were the commonest fish identified from stomach contents of elephant seals, but, owing to their small size, they amounted to a low biomass and were sometimes con- 
sidered as secondary prey of squid (Slip 1995, Daneri \& Carlini 2002, Field et al. 2007). Milk fatty acid concentration analysis indicated that elephant seal females may indeed feed on myctophids and/or on the larger Patagonian toothfish (Brown et al. 1999). A few otoliths of toothfish were recovered from seal stomach contents (Slip 1995, Field et al. 2007), but its high $\delta^{15} \mathrm{~N}$ and $\delta^{13} \mathrm{C}$ values precluded the species being a significant prey of female elephant seals at Kerguelen.

In the same way, most of the main species of cephalopods eaten by elephant seals (third dataset) had $\delta^{13} \mathrm{C}$ and $\delta^{15} \mathrm{~N}$ values precluding them as important dietary items of seals at the end of winter. $\delta^{13} \mathrm{C}$ values for Psychroteuthis glacialis and Slosarczykovia circumantarctica were too low, and $\delta^{15} \mathrm{~N}$ values for Gonatus antarcticus, onychoteuthids (the major squid prey at Heard Island on the Kerguelen Plateau) and Histioteuthis eltaninae were too high when compared to seal $\delta^{13} \mathrm{C}$ and $\delta^{15} \mathrm{~N}$ values, respectively. Such a high $\delta^{15} \mathrm{~N}$ value of oceanic squid is the likely explanation of the elevated blood $\delta^{15} \mathrm{~N}$ value of the most specialized cephalopod-eating seabird from the Southern Ocean, the wandering albatross, which, accordingly, shows a higher TL than elephant seals (4.6 versus 5.7, authors' unpubl. data). Among squid, only ommastrephid juveniles (Martialia hyadesi and Todarodes sp.) had $\delta^{13} \mathrm{C}$ and $\delta^{15} \mathrm{~N}$ values that fit well with those of theoretical prey of elephant seals. Ommastrephids are common (but not the main) food items of seals from South Georgia and Macquarie, but not at Heard Island (Rodhouse et al. 1992, Green \& Burton 1993, Slip 1995). Accordingly, only one ommastrephid beak (of a total of 57 beaks retrieved from 7 seals, authors' unpubl. data) was identified in a preliminary dietary investigation, suggesting that they are not important elephant seal prey at Kerguelen, at least at the very end of their foraging trip.

Isotopic data of elephant seals and of their potential prey items are consistent with a diet dominated by myctophids, but, theoretically, they cannot preclude the possibility that seals fed on a mixed diet including fish and squid, or even solely a variety of squid (e.g. a mixture of species having high and low $\delta^{15} \mathrm{~N}$ values leading to an integrated intermediate value for elephant seals). However, a reassessment of both stomach content and fatty acid data also suggests that cephalopods are not the staple food of female elephant seals. The 2 main arguments supporting the hypothesis that seals are mainly teuthivorous consumers are the longrecognized presence of cephalopod beaks in their stomach (Rodhouse et al. 1992, Green \& Burton 1993), and the recent finding that some of their blubber fatty acid profiles classify with those of squid (Bradshaw et al. 2003). As previously discussed, chitinized beaks of cephalopods resist digestion better than fish items; consequently, they accumulate over time, leading to an overestimation of cephalopods in the diet of consumers (Rodhouse et al. 1992). Another key, but previously unrecognized, issue is that analyzed stomach contents of elephant seals contain fewer beaks than those of the squid-eating toothed whales (usually 10s versus 100s to 1000s) (Whitehead et al. 2003), but about the same order of magnitude as food samples of many crustacean- and fish-eating predators, including king penguins (Cherel et al. 2002). Interestingly, king penguins were initially considered squid consumers on the basis of beaks collected from fasting individuals (Croxall \& Prince 1980) before subsequent dietary and lipid analyses recognized them as the most specialized myctophid-eating seabird from the Southern Ocean (Raclot et al. 1998, Cherel et al. 2002).

The second argument is that some elephant seal lipid profiles correlate better with squid than with fish profiles (Bradshaw et al. 2003). However, the taxonomic resolution of statistical analysis of fatty acid patterns in the study was coarse (i.e. fish versus squid, Bradshaw et al. 2003), while fish lipid patterns show considerable taxonomic variation (at the species and family levels), thus allowing separation of fishes into functional groups for a better predator-prey analysis (Connan et al. 2007a,b). Moreover, due to the importance of prey lipids in the digestive gland of squid (that exceed mantle lipid content by an order of magnitude), it is important to consider the type of squid fatty acid data included in dietary studies of top predators (Jackson et al. 2007). When whole squid and/or digestive gland are used to represent potential prey items (e.g. Bradshaw et al. 2003), the squid lipid profile may be very similar to other prey such as myctophids, thus constraining the use of fatty acids to assess the importance of squid in the diet of predators (Jackson et al. 2007). Within that context, it is remarkable that lipid analysis classified elephant seals with squid known to be primarily myctophid eaters (Phillips et al. 2002, 2003), and that seals had a $\delta^{15} \mathrm{~N}$ value not statistically different from that of the mesopelagic fish-eating warty squid (Cherel \& Duhamel 2003).

In summary, a thorough comparison of $\delta^{15} \mathrm{~N}$ and $\delta^{13} \mathrm{C}$ values of predators, prey and elephant seals supports the hypothesis that the main prey of female elephant seals are myctophid fishes, not squid. We therefore suggest that they occupy a unique ecological niche amongst the guild of subantarctic and Antarctic air-breathing diving vertebrates by feeding on mesopelagic fish at great depths. Elephant seals routinely dive much deeper than penguins and other seals (Hindell et al. 1991), making them, together with the squid-eating toothed whales, the only warm-blooded consumers physiologically capable of foraging in the deep. At depths > $300 \mathrm{~m}$, they may target both migrating myctophids and the non-migrating 
deepest living mesopelagic fish. Noticeably, myctophids descend to greater depths (350 to $500 \mathrm{~m}$ ) in winter (Kozlov 1995), and thus are largely unavailable to king penguins at that time, but not to female elephant seals. At depth, the most significant competitors of seals for food resources are probably oceanic squid; the little information available indicates that these major consumers target primarily mesopelagic fish (Lubimova 1985). Foraging in the same habitat and on the same prey is therefore the likely explanation why female elephant seals opportunistically include some squid in their diet.

In the present study, a small variance in $\delta^{15} \mathrm{~N}$ values of female elephant seals was observed over a larger range of $\delta^{13} \mathrm{C}$ values, suggesting that all female seals fed at the same TL and on the same prey whatever their foraging zones. Within that context it is noticeable that the $\delta^{15} \mathrm{~N}$ value of the main Antarctic myctophid Electrona antarctica was almost identical in both Kerguelen (the present study) and high-Antarctic waters (Rau et al. 1992), suggesting little latitudinal variation in myctophid $\delta^{15} \mathrm{~N}$ value. However, more information is needed on the $\delta^{15} \mathrm{~N}$ values of other potential prey in the Southern Ocean to better define the isotopic niche of elephant seals. The present study focused on adult female elephant seals at Kerguelen Islands, but elsewhere in the Southern Ocean, females also forage in oceanic waters (McConnell \& Fedak 1996, Campagna et al. 1998, Jonker \& Bester 1998, Hindell et al. 2003) where myctophids dominate the mesopelagic fish assemblage (Kozlov 1995). Therefore, female southern elephant seals may target myctophid fish, and to a lesser extent squid, across their wide geographic distribution. Elephant seals are highly sexually dimorphic as adults and pronounced sexual and ontogenic differences were found in the feeding ecology of the species (Slip et al. 1994, Field et al. 2007). Further investigation on males, immature animals and females at other locations are required for better overall knowledge of the trophic relationships of southern elephant seals. Nevertheless, the present study adds new information on the poorly documented composition of southern elephant seal food, which can be used to improve prey-consumption models and, thus, our understanding of the functioning of the pelagic ecosystem (Hindell et al. 2003). It also emphasizes the role of mesopelagic fish in the Southern Ocean as a link between meso- and macrozooplankton and large predators foraging in oceanic waters (Kozlov 1995, Connan et al. 2007b).

Acknowledgements. The authors thank scientists and fieldworkers who helped collect samples on land and at sea, and G. Guillou for stable isotope analysis. The present work was supported financially and logistically by the Agence Nationale de la Recherche Programme Vulnérabilité (Investi- gation of the vulnerability of the biological productivity of the Southern Ocean subsystems to climate change: the southern elephant seal assessment from mid to high latitudes), the Institut Polaire Français Paul Emile Victor (IPEV, Programme No. 109, H. Weimerskirch), and the Terres Australes et Antarctiques Françaises.

\section{LITERATURE CITED}

Altabet MA, François R (1994) Sedimentary nitrogen isotopic ratio as a recorder for surface ocean nitrate utilization. Global Biogeochem Cycles 8:103-116

> Biuw M, Boehme L, Guinet C, Hindell M and others (2007) Variations in behavior and condition of a Southern Ocean top predator in relation to in situ oceanographic conditions. Proc Natl Acad Sci USA 104:13705-13710

> Bradshaw CJA, Hindell MA, Best NJ, Phillips KL, Wilson G, Nichols PD (2003) You are what you eat: describing the foraging ecology of southern elephant seals (Mirounga leonina) using blubber fatty acids. Proc R Soc Lond Biol Sci 270:1283-1292

> Brown DJ, Boyd IL, Cripps GC, Butler PJ (1999) Fatty acid signature analysis from the milk of Antarctic fur seals and southern elephant seals from South Georgia: implications for diet determination. Mar Ecol Prog Ser 187:251-263

Campagna C, Quintana F, Le Boeuf BJ, Blackwell S, Crocker DE (1998) Diving behaviour and foraging ecology of female southern elephant seals from Patagonia. Aquat Mamm 24:1-11

Cherel Y (2008) Isotopic niches of emperor and Adélie penguins in Adélie Land, Antarctica. Mar Biol 154:813-821

Cherel Y, Duhamel G (2003) Diet of the squid Moroteuthis ingens (Teuthoidea: Onychoteuthidae) in the upper slope waters of the Kerguelen Islands. Mar Ecol Prog Ser 250: 197-203

Cherel Y, Hobson KA (2005) Stable isotopes, beaks and predators: a new tool to study the trophic ecology of cephalopods, including giant and colossal squids. Proc R Soc Lond B Biol Sci 272:1601-1607

> Cherel Y, Hobson KA (2007) Geographical variation in carbon stable isotope signatures of marine predators: a tool to investigate their foraging areas in the Southern Ocean. Mar Ecol Prog Ser 329:281-287

Cherel Y, Pütz K, Hobson KA (2002) Summer diet of king penguins (Aptenodytes patagonicus) at the Falkland Islands, southern Atlantic Ocean. Polar Biol 25:898-906

> Cherel Y, Hobson KA, Bailleul F, Groscolas R (2005a) Nutrition, physiology, and stable isotopes: new information from fasting and molting penguins. Ecology 86:2881-2888

Cherel Y, Hobson KA, Hassani S (2005b) Isotopic discrimination between food and blood and feathers of captive penguins: implications for dietary studies in the wild. Physiol Biochem Zool 78:106-115

Cherel Y, Hobson KA, Guinet C, Vanpé C (2007) Stable isotopes document seasonal changes in trophic niches and winter foraging individual specialisation in diving predators from the Southern Ocean. J Anim Ecol 76:826-836

> Connan M, Cherel Y, Mabille G, Mayzaud P (2007a) Trophic relationships of white-chinned petrels from Crozet Islands: combined stomach oil and conventional dietary analyses. Mar Biol 152:95-107

Connan M, Cherel Y, Mayzaud P (2007b) Lipids from stomach oil of procellariiform seabirds document the importance of myctophid fish in the Southern Ocean. Limnol Oceanogr 52:2445-2455

Croxall JP, Prince PA (1980) Food, feeding ecology and eco- 
logical segregation of seabirds at South Georgia. Biol J Linn Soc 14:103-131

Daneri GA, Carlini AR (2002) Fish prey of southern elephant seals, Mirounga leonina, at King George Island. Polar Biol 25:739-743

Ducatez S, Dalloyau S, Richard P, Guinet C, Cherel Y (2008) Stable isotopes document winter trophic ecology and maternal investment of adult female southern elephant seals (Mirounga leonina) breeding at the Kerguelen Islands. Mar Biol 155:413-420

Field IA, Bradshaw CJA, van den Hoff J, Burton HR, Hindell MA (2007) Age-related shifts in the diet composition of southern elephant seals expand overall trophic niche. Mar Biol 150:1441-1452

Gaskett AC, Bulman C, He X, Goldsworthy SD (2001) Diet composition and guild structure of mesopelagic and bathypelagic fishes near Macquarie Island, Australia. NZ J Mar Freshw Res 35:469-476

Green K, Burton HR (1993) Comparison of the stomach contents of southern elephant seals, Mirounga leonina, at Macquarie and Heard Islands. Mar Mamm Sci 9:10-22

Guinet C, Cherel Y, Ridoux V, Jouventin P (1996) Consumption of marine resources by seabirds and seals in Crozet and Kerguelen waters: changes in relation to consumer biomass 1962-85. Antarct Sci 8:23-30

Hilderbrand GV, Farley SD, Robbins CT, Hanley TA, Titus K, Servheen C (1996) Use of stable isotopes to determine diets of living and extinct bears. Can J Zool 74:2080-2088

Hindell MA, Slip DJ, Burton HR (1991) The diving behaviour of adult male and female southern elephant seals, Mirounga leonina (Pinnipedia: Phocidae). Aust J Zool 39: 595-619

> Hindell MA, Bradshaw CJA, Sumner MD, Michael KJ, Burton HR (2003) Dispersal of female southern elephant seals and their prey consumption during the austral summer: relevance to management and oceanographic zones. J Appl Ecol 40:703-715

- Hobson KA, Cherel Y (2006) Isotopic reconstruction of marine food webs using cephalopod beaks: new insight from captively raised Sepia officinalis. Can J Zool 84:766-770

Hobson KA, Schell DM, Renouf D, Noseworthy E (1996) Stable carbon and nitrogen isotopic fractionation between diet and tissues of captive seals: implications for dietary reconstructions involving marine mammals. Can J Fish Aquat Sci 53:528-533

- Hobson KA, Fisk A, Karnovsky N, Holst M, Gagnon JM, Fortier M (2002) A stable $\left(\delta^{13} \mathrm{C}, \delta^{15} \mathrm{~N}\right)$ model for the North Water food web: implications for evaluating trophodynamics and the flow of energy and contaminants. DeepSea Res II 49:5131-5150

Jackson GD, Bustamante P, Cherel Y, Fulton A and others (2007) Applying new tools to cephalopod trophic dynamics and ecology: perspectives from the Southern Ocean Cephalopod Workshop, February 2-3, 2006. Rev Fish Biol Fish 17:79-99

- Jonker FC, Bester MN (1998) Seasonal movements and foraging areas of adult southern female elephant seals, Mirounga leonina, from Marion Island. Antarct Sci 10: 21-30

Kelly JF (2000) Stable isotopes of carbon and nitrogen in the study of avian and mammalian trophic ecology. Can J Zool 78:1-27

Kozlov AN (1995) A review of the trophic role of mesopelagic fish of the family Myctophidae in the Southern Ocean ecosystem. CCAMLR Sci 2:71-77

Lea MA, Guinet C, Cherel Y, Duhamel G, Dubroca L, Pruvost P, Hindell MA (2006) Impacts of climatic anomalies on provisioning strategies of a Southern Ocean predator. Mar Ecol Prog Ser 310:77-94

Lesage V, Hammill MO, Kovacs KM (2002) Diet-tissue fractionation of stable carbon and nitrogen isotopes in phocid seals. Mar Mamm Sci 18:182-193

Lescroël A, Bost CA (2005) Foraging under contrasting oceanographic conditions: the gentoo penguin at Kerguelen Archipelago. Mar Ecol Prog Ser 302:245-261

> Lewis R, O'Connell TC, Lewis M, Campagna C, Hoelzel AR (2006) Sex-specific foraging strategies and resource partitioning in the southern elephant seal (Mirounga leonina). Proc R Soc Lond B Biol Sci 273:2901-2907

Lourey MJ, Trull TW, Sigman DM (2003) Sensitivity of $\delta^{15} \mathrm{~N}$ of nitrate, surface suspended and deep sinking particulate nitrogen to seasonal nitrate depletion in the Southern Ocean. Global Biogeochem Cycles 17:1081-1098

Lubimova TG (1985) Results of Soviet investigations of the distribution and ecology of pelagic squids (Oegopsida) in the Southern Ocean. CCAMLR Select Sci Pap 1985: 79-111

> McConnell BJ, Fedak MA (1996) Movements of southern elephant seals. Can J Zool 74:1485-1496

> Park YH, Gambéroni L (1997) Cross-frontal exchange of Antarctic Intermediate Water and Antarctic Bottom Water in the Crozet Basin. Deep-Sea Res II 44:963-986

Perissinotto R, Pakhomov EA (1998) The trophic role of the tunicate Salpa thompsoni in the Antarctic marine ecosystem. J Mar Syst 17:361-374

> Phillips KL, Nichols PD, Jackson GD (2002) Lipid and fatty acid composition of the mantle and digestive gland of four Southern Ocean squid species: implications for food-web studies. Antarct Sci 14:212-220

Phillips KL, Nichols PD, Jackson GD (2003) Dietary variation of the squid Moroteuthis ingens at four sites in the Southern Ocean: stomach contents, lipid and fatty acid profiles. J Mar Biol Assoc UK 83:523-534

Raclot T, Groscolas R, Cherel Y (1998) Fatty acid evidence for the importance of myctophid fishes in the diet of king penguins, Aptenodytes patagonicus. Mar Biol 132:523-533

Rau GH, Ainley DG, Bengtson JL, Torres JJ, Hopkins TL (1992) ${ }^{15} \mathrm{~N} /{ }^{14} \mathrm{~N}$ and ${ }^{13} \mathrm{C} /{ }^{12} \mathrm{C}$ in Weddell Sea birds, seals, and fish: implications for diet and trophic structure. Mar Ecol Prog Ser 84:1-8

- Ridoux V, Offredo C (1989) The diets of five summer breeding seabirds in Adélie Land, Antarctica. Polar Biol 9:137-145

Rodhouse PG, Arnbom TR, Fedak MA, Yeatman J, Murray AWA (1992) Cephalopod prey of the southern elephant seal, Mirounga leonina L. Can J Zool 70:1007-1015

Santos MB, Clarke MR, Pierce GJ (2001) Assessing the importance of cephalopods in the diets of marine mammals and other top predators: problems and solutions. Fish Res 52: $121-139$

Slip DJ (1995) The diet of southern elephant seals (Mirounga leonina) from Heard Islands. Can J Zool 73:1519-1528

Slip DJ, Hindell MA, Burton HR (1994) Diving behavior of southern elephant seals from Macquarie Island: an overview. In: Le Boeuf BJ, Laws RM (eds) Elephant seals. Population ecology, behavior and physiology. University of California Press, Berkeley, CA, p 253-270

Sweeting CJ, Barry J, Barnes C, Polunin NVC, Jennings S (2007) Effects of body size and environment on diettissue $\delta^{15} \mathrm{~N}$ fractionation in fishes. J Exp Mar Biol Ecol 340:1-10

- Whitehead H, MacLeod CD, Rodhouse P (2003) Differences in niche breadth among some teuthivorous mesopelagic marine mammals. Mar Mamm Sci 19:400-406 